\title{
FICTIONALISING THE UNSPEAKABLE: GUILLERMO DEL TORO'S CRIMSON PEAK (2015) AS A TRAUMA NARRATIVE*
}

\author{
Dina Pedro \\ Universidad de Valencia
}

\begin{abstract}
Neo-Victorian narratives of trauma display a temporal duplicity in addressing nineteenthcentury traumas that still prevail at present, including natural catastrophes, wars, or more personal and insidious traumas, such as domestic violence and oppression, or child and sexual abuse. In this article, I argue that Guillermo del Toro's neo-Victorian film Crimson Peak (2015) is constructed as a trauma narrative that exploits the trope of «the uncanny» (Freud 1919) and its main representations -i.e. the double, the return of the dead and repetition compulsion- to address the traumatic experience of gender violence and its impact on both Victorian and contemporary women. Furthermore, I contend that the film functions as a symbolical space where the audience can bear witness to and reflect on the multitemporal trauma of gender violence. That way, viewers can bear witness and develop empathy towards survivors of this traumatic experience.
\end{abstract}

KEYWORDS: neo-Victorianism on screen, trauma narratives, the uncanny, gender violence, working through.

FICCIONALIZAR LO INDECIBLE: CRIMSON PEAK (2015)

DE GUILLERMO DEL TORO COMO UNA NARRATIVA DE TRAUMA

\section{RESUMEN}

Las narrativas de trauma neovictorianas muestran una duplicidad temporal al abordar traumas del siglo Xıx que aún están presentes en la actualidad, incluyendo catástrofes naturales, guerras, o traumas más personales e insidiosos, como la violencia y la opresión de género, o el abuso infantil y sexual. En este artículo, defendemos que la película neovictoriana de Guillermo del Toro Crimson Peak (2015) está construida como una narrativa de trauma que explota el tropo de "lo siniestro» (Freud 1919) y sus principales representaciones -el doble, el regreso de los muertos y la repetición compulsiva- para tratar la experiencia traumática de la violencia de género y su impacto tanto en las mujeres victorianas como en las contemporáneas. Además, afirmamos que la película funciona como un espacio simbólico donde la audiencia puede ser testigo y reflexionar sobre el trauma multitemporal de la violencia de género. De esta manera, los espectadores pueden ser testigos y desarrollar empatía hacia supervivientes de esta experiencia traumática.

Palabras Clave: neovictorianismo audiovisual, narrativas de trauma, lo siniestro, violencia de género, superación.

DOI: https://doi.org/10.25145/j.refiull.2021.43.11

Revista de Filología, 43; julio 2021, pp. 213-232; ISSN: e-2530-8548 


\section{INTRODUCTION}

Crimson Peak (2015) is a neo-Victorian film by Mexican director Guillermo del Toro that addresses traumas and taboos within the dysfunctional nuclear family in Victorian England. The film follows Edith Cushing, an aspiring American novelist from a wealthy family hailing from Buffalo, New York. After her father's death, she hastily marries one of her suitors, Sir Thomas Sharpe, an impoverished British aristocrat that is trying to save the family business with foreign capital. Edith moves with Thomas and his sister, Lucille Sharpe, to their family estate in rural England, Allerdale Hall, where she soon discovers that they are hiding several family secrets. First, the Sharpe siblings have been involved in an incestuous relationship since they were children, as a coping mechanism for the abuse they had to endure at the hands of their own mother (Pedro 2020). Second, Thomas had previously married other three foreign affluent women before Edith and later killed them, so as to keep their fortunes and invest them in the family business. These murdered women come back from the dead as ghostly apparitions and try to protect Edith from the siblings' perfidious plans. At the end of the film, Edith remains the only female survivor, and, as I argue in this article, she translates all these horrors into her own trauma narrative: the film itself. This is so because Edith is both the narrator and the focaliser of Crimson Peak, and the audience follows the story through her perspective.

Del Toro has been internationally acclaimed for other Gothic and historical films, including the Spanish-language movies The Devil's Backbone (2001) and its companion, Pan's Labyrinth (2006), which are Gothic re-imaginings of the Spanish Civil War seen through the eyes of children. Both films include supernatural characters that are "misunderstood and alienated by the human population" (McDonald and Clark 2014: 3), but function as guides and helpers of the main characters. Del Toro also exploits this supernatural trope in Crimson Peak, where Edith can communicate with female ghosts, and eventually realises that they are actually their helpers, rather than evil monsters. In fact, it is usually the human characters that show a lack of morality in Del Toro's films (McDonald and Clark 2014: 3), as in the case of the Sharpe siblings, who are the true villains of Crimson Peak. Moreover, in these Gothic historical films, Del Toro rewrites the past to recover the stories of those that have been silenced by hegemonic historical accounts. In the case of Crimson Peak, its Victorian setting allows Del Toro to address the everpresent traumatic experience of gender violence and its after-effects, still prevalent in contemporary societies. This way, the director encourages the audience to reflect

* Research for this article was conduced with the financial aid of a predoctoral grant funded by the Spanish Ministry of Science and Universities (Ref. FPU 17/03064) and the "Orion" research project: "Orientation: Towards a Dynamic Understanding of Contemporary Fiction and Culture», funded by the Spanish Ministry of Economy, Industry and Competitivity (FF 12017-P; Pl: Prof. Rosario Arias). 
on this timeless issue from both contemporary and Gothic perspectives through the exploitation of the trope of "the uncanny» (Freud 1919), particularly the double, the process of repetition compulsion of trauma and, especially, the return of the dead.

As Keith McDonald and Roger Clark assert, Del Toro shows an immense knowledge of both high and popular culture in his films, which are all inspired by Gothic literature in general, and the Victorian Gothic tradition in particular (2014: 12). In fact, Crimson Peak echoes several Victorian Gothic classics, mainly the incestuous plotline and the crumbling mansion from Edgar Allan Poe's «The Fall of the House of Usher» (1839); the haunting presence of the husband's prior wives, which so uncannily resembles the stories depicted in both Charlotte Brontë's Jane Eyre (1847) and Daphne du Maurier's Rebecca (1938); or the oppressive and Gothic atmosphere from northern rural England, evocative of Emily Brontë's Wuthering Heights (1847). However, rather than merely incorporating intertextual references to canonical texts, Del Toro «alters, blends or up-turns his referent in order to produce new meaning and re-contextualisation" (2014: 12). This is the case of Crimson Peak, which is constructed as a cinematic collage of Victorian literary referents and postmodern transformations. The purpose behind the construction of this cinematic collage is to both update Victorian classics for a contemporary audience -who might not be familiarised with the original literary referents- and to bring to the fore the stories of marginalised characters that were ignored in Victorian texts, particularly the madwoman in the attic and the abused wife. However, some critics claim that one of the film's biggest flaws is actually Del Toro's excessive exploitation of Victorian aesthetics, with the risk of turning it into a "pastiche» (Scott 2015).

In the following pages, I first provide a brief contextualisation of neoVictorian studies. Next, I introduce the framework of trauma studies -Freudian theory, particularly on uncanny phenomena (Freud 2001 [1919]), as well as the role of trauma narratives in helping the audience access trauma experience (Vickroy 2002)and its application to neo-Victorianism (Kohlke and Gutleben 2010), through the trope of haunting and spectrality (Arias and Pulham 2009). Against this theoretical background, and through a close reading of Crimson Peak, I then examine how Del Toro constructs the film as a trauma narrative that exploits the trope of the uncanny to tackle the traumatic experience of gender violence. I argue that Crimson Peak is constructed as Edith's trauma narrative, whereby she articulates the pain that she and Thomas's previous wives have endured in Allerdale Hall, so that the audience can bear witness to it.

\section{VISUAL NEO-VICTORIANISM}

Neo-Victorianism is a recent cultural project stemming from postmodernism that entails contemporary re-imaginings of the long nineteenth century in literature, music, (video)games, the visual arts and other cultural phenomena. The genre dates back to the 1960s, with the publication of Jean Rhys's Wide Sargasso Sea (1966) and John Fowles's The French Lieutenant's Woman (1969), which are considered to be the two founding texts of the genre. However, it was not until the 1990s that 
neo-Victorianism achieved mainstream success, thanks to the publication of A.S. Byatt's Possession: A Romance (1990) -and its subsequent adaptation on screen in 2002-, as well as the production of the popularly acclaimed BBC adaptation of Jane Austen's Pride and Prejudice (1812) in 1995, which became a massive hit on both sides of the Atlantic.

Indeed, neo-Victorianism is increasingly proliferating on both the big and the small screens, including films, TV series or video games. Chris Louttit and Erin Louttit (2018: 1) claim that, due to the popular acclaim of Victorian adaptations, the film industry as well as TV networks and digital platforms, like Netflix, HBO or Amazon Studios, are currently producing them. This is especially the case of TV series -e.g. Penny Dreadful (2014-2016), Frankenstein's Chronicles (2015-2017), Taboo (2017-), Carnival Row (2019-) or Dracula (2020) -and films- Cary Fukunaga's Jane Eyre (2011), Guillermo del Toro's Crimson Peak (2015) itself, or Netflix original Enola Holmes (2020). Antonija Primorac suggests that the increasing production of these neo-Victorian screen works show a present need to reinterpret the past by translating it into a medium and a language that can be more attractive and comprehensible for contemporary audiences (2018: 1).

Furthermore, Louisa Hadley asserts that neo-Victorian visual and textual narratives address both Victorian and contemporary periods, as they adopt a "dual approach» or concern for both the past and the present (2010: 6). In doing so, neo-Victorian fiction follows in (neo-)Gothicism's footsteps in that they both selfreflexively return to the past in order to resurrect our historical horrors, so as to help us «elucidate our present cultural anxieties and fears» (Maier and Ayres 2020: 6). Neo-Victorianism often intersects with neo-Gothicism, as in the case of Crimson Peak, in order to make real our (post)postmodern anxieties through fiction, but also to look back to the past for answers to our precarious modern situation ${ }^{1}$. Indeed, the combination of these two cultural phenomena -neo-Victorian Gothic- serves like no other to help us reflect on our present concerns by resurrecting Victorian ghosts - which would stand for Victorian anxieties and fears. This latter aspect is deeply enriching from an ethical perspective, as it establishes a dialogical relationship between the Victorian and contemporary periods, and offers a fictional space where the audience can address contemporary anxieties that might have originated in the nineteenth century - e.g. social and economic changes, the dysfunctional nuclear family or gendered traumas. As I argue in this article, this appears to be the case of Crimson Peak, since the traumas portrayed in the film mirror our contemporary ones, specifically gender violence within the family.

${ }^{1}$ For further information on neo-Victorian Gothic fiction see Kohlke, Marie-Luise and Christian Gutleben, eds. 2012. Neo-Victorian Gothic. Horror, Violence and Degeneration in the Re-Imagined Nineteenth Century. Amsterdam: Rodopi. 


\section{TRAUMA STUDIES}

The application of trauma studies to the humanities dates back to the pioneering work of a group of scholars belonging to the Yale School of Deconstruction, including Cathy Caruth, Shoshana Felman or Dominick LaCapra. They were the first to apply the founding theories of trauma studies to the analysis of Holocaust narratives, while drawing on several critical schools, including Freudian theories, feminism, New Historicism and the School of Deconstruction (Onega and Ganteau 2011: 9). The rise of trauma studies in the humanities took place during the 1980s and the 1990s, coinciding with an increase in public awareness and interest in trauma narratives.

Laurie Vickroy points to the crucial role of trauma narratives - «fictional narratives that help readers access traumatic experience» (2002: 1) - in bearing witness to both personal and collective traumas in the last two centuries, including the impact of colonialism, world wars, domestic violence or sexual abuse. Vickroy further contends these narratives also reproduce the main features of traumatic experience, including «silence, simultaneous knowledge and denial, dissociation, resistance and repression, among others» (2002: 3). Popular culture has often exploited the sensational aspects of trauma narratives, but their goal is to allow readers and viewers to develop a sympathetic engagement with «imaginings of humanity in extremis» (Vickroy 2002: 2). I contend that the neo-Victorian film Crimson Peak serves this purpose, as it does not merely exploit the dramatic aspects of human suffering, but rather enables the audience to access trauma, so that they can empathise with the traumatised characters and reflect on their experiences. Moreover, L. Juliana Claassens claims that trauma theory has traditionally been associated to either large-scale tragedies and the experiences of white men, so that the term «insidious trauma» was later coined in order «to be more inclusive of experiences pertaining to gender, race, class and sexual orientation" and to acknowledge that "female bodies [...] are bodies in pain» (2020: 11). This is the case of Crimson Peak, as it tackles the insidious trauma of gender violence, and contextualises it in the nineteenth century, a historical period that was key for incipient feminism and gender equality. Indeed, according to Marie-Luise Kohlke and Christian Gutleben, the Victorian era has progressively become a central point of research on historical trauma through the study of its actual disasters, but also from the perspective of fiction, as a re-invented and delayed "working-through" ${ }^{2}$ in neo-Victorianism (2010: 1). Kohlke and Gutleben further argue that neo-Victorian works are, in fact, a belated catharsis of nineteenth-century traumas, as well as contemporary ones, since «neo-Victorian fiction highlights interconnections between acts of aggravated historical violence

2 LaCapra establishes a distinction between «acting out» and "working through». While with the former the traumatized patient seems to be «haunted or possessed by the past» and is, therefore, condemned to compulsively repeat the traumatic experience, the latter would entail «the effort to articulate or rearticulate affect and representation in a manner that may [...] counteract, a reenactment, or acting out, of that disabling dissociation» (2001: 42). 
and their long-term cultural and political aftershocks still resonating well into the twentieth and twenty-first centuries» (2010:3). Neo-Victorianism not only addresses historical trauma, but also explores more private and insidious situations that evoke contemporary horrors, including gender violence or child abuse. Thus, neo-Victorian representations of trauma arguably mirror our own contemporary sufferings and directly contribute to our current trauma research (Kohlke and Gutleben 2010: 3).

Moreover, trauma theory has long been associated with the trope of haunting and spectrality in neo-Victorian fiction, especially in terms of uncanny phenomenology. Rosario Arias and Patricia Pulham argue that neo-Victorianism produces a sense of dejà $v u$ on readers that is uncanny in nature. Freud's uncanny phenomena (2001 [1919]) include "the double; repetition; the animation of the seemingly dead or, conversely, the death-like nature of the seemingly animate; ghosts or spirits; and the familiar made strange». Indeed, neo-Victorianism represents a double of Victorian literature in its imitation of nineteenth-century culture; it appropriates Victorian tropes and reinterprets historical events; it resuscitates Victorian genres and characters; and it defamiliarises our established conceptions the Victorian. Consequently, neo-Victorian fiction could be interpreted as nineteenthcentury apparition that permeates our present in order to make us reflect about both Victorian and contemporary issues (Arias and Pulham 2009: xv).

Taking all this into consideration, in the following pages I determine how Crimson Peak is constructed as a trauma narrative that explores nineteenth-century gendered traumas that evoke present anxieties of the same nature. I argue that the film should be understood as a cinematic text that bridges a historical gap between the Victorians and us in terms of traumatic experience, and as a fictional space where contemporary audiences can bear witness to the traumas experienced by trauma survivors of gender violence from both periods.

\section{CRIMSON PEAK(2015) AS A TRAUMA NARRATIVE}

As noted above, neo-Victorian Gothic fiction frequently exploits uncanny phenomena as a way to address both Victorian and contemporary anxieties (Arias and Pulham 2009). This is the case of Crimson Peak, which depicts the horrors of domestic violence through this trope. The uncanny was defined by Freud as an occurrence associated «to what arouses dread and horror» (2001 [1919]: 219). It is an experience that is not triggered by something new or strange, but rather by something familiar that has been estranged from our minds through a process of repression, but eventually recurs (2001 [1919]: 241). Most people seem to experience uncanny sensations either when repressed childhood traumas are re-enacted by new impressions, or when our discarded primitive beliefs seem to be confirmed once again in the real world, including the return of the dead (Freud 2001 [1919]: 249). However, these two types of uncanny experiences are not always clearly distinguishable, especially when superstitious beliefs are closely related to childhood traumas, or are, in fact, triggered by them. In Crimson Peak, Edith, the female protagonist, has firmly believed in the existence of ghosts ever since her mother passed away. In the 
next fragment, which is Edith's first of her two voice-overs in the film, she explains that she was still very little the first time she saw her spectre:

Ghosts are real. This much I know. The first time I saw one I was 10 years old. It was my mother's. Black cholera had taken her. So Father ordered a closed casket, asked me not to look. There were to be no parting kisses. No goodbyes. No last words. That is, until the night she came back (Del Toro, 2015a: 00:01:02).

While trauma verbalisation has a wide range of possible linguistic traits and representations, some of the most common ones include repetition, fragmentation and the incorporation of emotional or sensory aspects to the victim's discourse (Busch and McNamara 2020: 330). In the example above, Edith's speech is made up of short sentences -which might be described as a fragmented discourse- and contains emotional and sensorial vocabulary related to death and mourning -e.g. «black cholera», «casket», «parting kisses» and "goodbye». Hence, this arguably reflects that her mother's loss was a turning point in her life; an event that was so frightening and overwhelming that traumatised her as a child, and was also the first of her many interactions with ghosts - which are considered to be an incorporeal representation of a past trauma. They represent the prevalence of a past tragedy and how it still haunts us in our present (Arias and Pulham 2009). The fact that her mother's ghost appears twice in the film -first when she is a child and later as an adult- proves that she is a persistent force from the past in Edith's present; an unresolved mourning that she needs to overcome. For Freud, the loss of a loved one can either cause a reaction of mourning or melancholia, both involving "grave departures from the normal attitude to life» (1957 [1917]: 243). While the former would imply a loss of interest in the outside reality, the latter also entails a decrease in self-esteem and self-respect (2001 [1917]: 244). In the case of mourning, an indeterminate period of time is needed to detach oneself from the lost object of love, but when the grieving process has been completed, the ego is free to pursue other interests (2001 [1917]: 252). I argue that Edith has not overcome her mother's death during most part of the film, since she still feels attached to her presence in the form of a ghost, and later writes ghost stories based on that experience. It is not until the end of the film, when she kills Lucille -the main perpetrator of Crimson Peak- and constructs her experience as a trauma narrative, that she might work through her traumatic past.

Indeed, the lack of a mother figure who could offer Edith guidance and protection triggered a sense maternal abandonment in her. This was later compensated in the form of her mother's ghost, who acts as a guardian spirit that tries to warn and protect her from the dangers that lie ahead. This ghost first appears when Edith was only a child, and later when she meets Sir Thomas Sharpe. In both cases, she warns her daughter about a place called Crimson Peak: «My child, when the time comes, beware of Crimson Peak» (Del Toro 2015a: 00:03:03), a direct reference to the Sharpe residence in the north of England. The Sharpe estate, originally called Allerdale Hall, is colloquially known as "Crimson Peak" because of the way the autochthone red clay stains the snow with a blood-red huge. However, at that point in the film neither Edith nor the audience know what that name refers to. Edith's lack of maternal love and guidance can be further demonstrated by the fact that 
all the ghosts that she meets throughout the film -her own mother and Thomas's mother and wives- are all females that try to save her from the siblings' pernicious plans. Even though she had a strong connection with her father, his ghost never appears to warn her about the siblings' intentions. Thus, I argue that these female ghosts should be considered as maternal figures that compensate the lack of an actual mother for Edith after she marries Thomas.

\section{THE ROLE OF WRITING IN VERBALISING TRAUMA}

Her mother's death and her subsequent return as a ghost are events that deeply traumatised Edith, to the point where she needs to verbalise them in order to make sense of them when she is an adult woman. According to Dori Laub, traumatised survivors have «an imperative need to tell» their painful experiences, so as to get to know their own buried stories, freed from the ghosts of the past (1992a: 78). Laub also stresses the importance of having an empathic witness that can help the survivor overcome their trauma, otherwise they might resort to silence (Laub 1992b: 69). Drawing on his theories of traumatic verbalisation, Susanne Gruss also stresses the capacity of neo-Victorian fiction to «explore the possibility of writing about trauma» (2014: 130), since it might allow the victims to work through their pain (2014: 131). In fact, for Kohlke and Gutleben, trauma is a performative process, as it only comes to life through its articulation and secondary witnessing. Hence, a trauma narrative would entail an act of generation, creating the «understanding, transmission, and healing of trauma» (2010: 28). In the case of Edith, the need to understand and transmit her traumatic experience happens during her adult life, when she starts to write ghost stories and unsuccessfully tries to get them published. I argue that these stories are meant to reconstruct her past experience with her mother's ghost in an attempt to work through it and so to start the healing process.

Along the same lines, LaCapra highlights the need to establish an «empathic unsettlement», which could be defined as the reader's need to develop empathy without completely identifying with or appropriating the survivor's experience, otherwise they might be traumatized by it (2001: 40). However, Kohke and Gutleben contend that neo-Victorian fiction allows the audience to develop an empathic connection with historical characters, so that we see «ourselves in (rather than in place of) the suffering victim and reciprocally encounters the self-as-other and the other-as-self by acknowledging our own vulnerability to traumatisation» (2010: 18). Thus, neo-Victorian fiction hinders LaCapra's concerns about vicarious trauma and unrestrained identification, and arguably enables the audience to experience their own susceptibility to trauma experience. There are two possible diegetic levels of empathy in the film. On the one hand, Edith needs to find an addressee within the story that can read and empathise with her trauma verbalisation -i.e. her ghost stories. On the other hand, there is the effect that Edith's trauma narrative might have on the audience of Crimson Peak.

Taking all this into consideration, trauma victims need to find a way to communicate their stories to others so as to achieve a sense of social acknowledgement. 
Suzette Henke suggests that one of these ways would be sciptotherapy, or «the process of writing out or writing through traumatic experience in the mode of therapeutic re-enactment». (Henke 1998: XII-XIII). In Crimson Peak, Edith attempts to articulate and so work through the trauma of losing her mother by fictionalizing it in the form of ghost stories. Her cathartic release is, therefore, attained through storytelling. Indeed, a common strategy to represent trauma in neo-Victorian fiction is through the use of metanarratives, given that «the mise en abyme of written or oral testimonies highlights the verbalisation of trauma as the central act of the novelistic apparatus" (Kohlke and Gutleben 2010: 27, emphasis in original). In the case of Edith, she transforms her trauma into fiction through ghost stories, and her potential readers would become the sympathetic listeners that can bear witness to her pain without fully identifying with it. Del Toro associates Edith with great nineteenth-century writers, such as Jane Austen or the Brontë sisters and their fictional heroines (Roche 2019: 85). At the beginning of the film, Edith is trying to get her first novel published, but her editor is reluctant to do so because her manuscript is a ghost story. He believes that this type of fiction cannot be considered serious literature, and that it would be more suitable for a female novelist to write love stories. As Hayley Arizona Roche asserts, the editor «reduces her work to the aesthetics of her penmanship» and tries to mute Edith by prompting her to write a love story, assuming that it is all she is capable of creating (2019: 85). This disregard for ghost narratives -as well as his strong opposition against female writers producing such fiction- was commonplace during the nineteenth century and is evocative of Jane Austen's novel Northanger Abbey (1817). Austen mocks the obsessive fascination that young ladies had for Gothic literature at the time, and warns against its potential dangers. Moreover, Lucille burns her manuscripts at the end of the film, so that her working through and the possibility of establishing an empathic bond with her potential readers is curtailed. The only person that gets to read her stories is Thomas -arguably the only one that can actually believe and empathise with her traumatic experience, as his family house is haunted by ghosts. As he tells Edith: «They've always fascinated me. You see, where I come from ghosts are not to be taken lightly» (Del Toro 2015a: 00:08:33). However, given that Thomas's intentions towards Edith are not pure -as he intends to kill her and keep her fortune- he cannot be the empathic listener that might help her overcome her trauma.

Furthermore, Edith not only interacts with her mother's ghost in the film, but also with Thomas's deceased mother and wives in Allerdale Hall. These female ghosts were murdered and abused by Lucille, who is trying to do the same to Edith. The second part of the film focuses on these cases of domestic violence and how the female ghosts in Allerdale Hall try to protect Edith from Lucille's violence. As a result, I argue that Crimson Peak should be considered as Edith's trauma narrative through which she works through her traumatic experiences in Allerdale Hall. This is demonstrated by the fact that she is its narrator and focaliser, as well as the only female survivor. Moreover, the last scene of the film mirrors the first one, showing a book closing and revealing the following words: «Crimson Peak by Edith M. Cushing» (Del Toro 2015a: 01:51:23). As Marine Galiné contends, in the end, Edith is the one that closes the book of her own life, which is arguably 
a symbol reminding the audience of the social obstacles female writers had to endure at the time (2020: 12). Whist Weeber wonders whether the story was just Edith's imagination or an autobiography with ghosts (2018: 119), and for Beatrice M. Murphy it proves that Edith has finally gotten the real-life experience that she needed to write a realistic account of love and violence through her "meta-framing device» (2016: 162), I contend that this clearly shows that the film is built as a trauma narrative whereby Edith verbalises her suffering. Just like she fictionalises her mother's unsuccessful mourning in the form of ghost stories, Crimson Peak itself should be interpreted as the cathartic release of her pain in Allerdale Hall. In doing so, she transforms her traumatic experience into storytelling and the audience bears witness to her and the other female characters' gendered traumas at the hands of the Sharpe siblings.

However, Edith claims that ghosts are not to be interpreted literally in her narratives, but rather as a «metaphor for the past» (Del Toro 2015a: 00:06:11). This assertion echoes Kate Mitchell's claim that the figure of the ghost is key in neoVictorian literature since it works as a metaphor for the haunting presence of the Victorian past and our connection with it at present (2010: 180), to which Gruss adds that it also allows us to summon both the literary and historical ghosts of our Victorian past (2014: 125). Consequently, the ghosts that appear both in Edith's metanarrative and in the film itself are arguably the embodiment of her past traumas, which haunt her in the present, but also serve as a metaphor for our contemporary engagement with the Victorian past.

\section{The Double AND RePeTITION COMPULSION IN CRIMSON PEAK}

After her father's death, Edith finds herself in a precarious position, since she does not have any other male living relatives. As Charles Petrie states, according to Victorian codes of female behaviour, the only way for a middle-class woman to rise up in the world was to marry a suitable husband (Petrie 2000: 180). Hence, Edith is forced to hastily marry one of her suitors, Sir Thomas Sharpe, and move with him and his sister Lucille to England. At first, Edith is oblivious to the fact that Thomas has previously married and murdered other three wealthy women in order to inherit their fortunes, but they have returned as ghosts to warn her of the siblings' intentions.

As Emilia Musap points out, since the Victorian era, the family house has become a «site for uncanny disturbances». In the case of Allerdale Hall in Crimson Peak, the family mansion displaces its residents while simultaneously placing them in a seemingly safe environment (Musap 2017: 4). The Sharpe house bore witness to a number of family traumas that shaped its residents and turned them from victims to perpetrators. Although these traumas are not explicitly portrayed in the film as they occurred years before the events depicted in it-, Lucille verbalises them by telling Edith about her and Thomas's childhood. First of all, the siblings' mother, Lady Sharpe, was a victim of gender violence perpetrated by her husband, as Lucille tells Edith when the latter is bedridden, after being repeatedly poisoned: «I tended 
Mother in this bed. Father was a brute. He hated Mother. Broke her leg. Snapped it in two under his boot. She never quite healed. She was bedridden for a long time. But I cared for her. Fed her. Bathed her. Combed her hair. Rubbed liniment on her scars. I made her better» (Del Toro 2015a: 01:24:04). However, Lady Sharpe later became a perpetrator against her two children, as she confined Lucille and Thomas in the attic and physically punished them. In the following fragment, Lucille points to her mother's parental neglect when she explains that she and Thomas could not play around the house and were mostly ignored by her: «We were not allowed in here as children. We were confined to the nursery in the attic. Mother played the piano sometimes. We'd hear her through the floor. That's how we knew she was back in the country" (Del Toro 2015a: 00:50:10). It seems that this lack of maternal love triggered an unnatural bond between the siblings, which eventually culminated in an incestuous relationship. Lucille verbalises this traumatic past when she tells Edith that this incestuous love made her protect her brother from their mother's abuse: «But you should have seen him, as a child, Thomas. He was perfect. So from all his small infractions, from my mother's cane, I protected him. I took so many beatings. And when she found out about us... Well, the only love Thomas and I ever knew was from one another in these rotting walls. Hiding» (01:38:51). Lucille also hints at the fact that they murdered their mother after she discovered their deviant relationship, which transformed them from victims to perpetrators. This was the first of a considerable number of murders -i.e. Edith's father and Thomas's three previous wives -that conform the siblings' compulsive cycle of violence. Although Lucille tries to justify their murderous pattern of behaviour through the verbalisation of their childhood trauma, Edith is not a sympathetic listener, as she still regards them as monsters and finds their actions aberrant and unjustifiable. Furthermore, I contend that Lucille and Thomas's murderous pattern of behaviour -which takes place in their family home and was triggered by their childhood trauma of domestic abuse- is arguably an example of Freud's uncanny, which he defines as repetition compulsion (2001 [1919]: 238). This phenomenon consists in an involuntary recurrence of the same situations, things or events that «does undoubtedly, subject to certain conditions and combined with certain circumstances, arouse an uncanny feeling» (2001 [1919]: 237). Even though these repetitions could be deemed by some as mere coincidences, they are surrounded by a dreadful feeling that it is actually something "fateful and inescapable», rather mere chance (2001 [1919]: 237). This seemingly endless cycle of murders appears to be inescapable, as the siblings have made it their only means of economic survival.

The incestuous nature of Thomas and Lucille's relationship takes us to the uncanny phenomenon of the double. For Freud, the double would refer to two people who look identical, but also share the same knowledge, emotions and vital experiences. These are people who identify themselves «with another person, so that his self becomes confounded, or the foreign self is substituted for his own -in other words, by doubling, dividing and interchanging the self». He also points to the frequent occurrence of similar situations, physical or personality traits, or even a similar crime (2001 [1919]: 234). The Sharpe siblings trigger this uncanny feeling in the audience, since they are portrayed as two parts of the same being. Weeber 
points out that, due to the child abuse that they were subject to, Lucille developed a split personality, "which she has filled by absorbing parts of her parents, of her brother and of the house» (2018: 123). Weeber further argues that Del Toro portrayed Lucille and Thomas to look like twins, since they wear the same colours, have similar physical traits (2018: 123), and share the same fundamental experiences -child abuse, a murderous past and an incestuous relationship. Their interdependency is shown in the following fragment, when they promise that they will never abandon one another (Del Toro 2015a: 01:26:38):

Lucille: We stay together. Never apart.

Thomas: Never apart.

Lucille: You couldn't leave me. You wouldn't.

Thomas: I can't. I can't.

Lucille: I know.

It is also worth noting how gender reversal is explored in the film, particularly in the case of Lucille and Thomas. Khara Lukancic claims that the male characters in Crimson Peak are passive and submissive, «existing in the background», while the female protagonists, Edith and Lucille, are the ones that "hold the agency" (2018). Indeed, Lucille is the active villain, as she is the one that commits all the hideous crimes - she stabs her mother in the head with a kitchen knife; she poisons Thomas's wives and attempts to do the same to Edith- and can be considered as «a penetrative and symbolically castrating, phallic mother surrogate» (Jamil 2018: 54) to Thomas, who does everything his sister dictates, acting as an emasculated character. Thus, Lucille assumes the active, violent and authoritative role in their relationship -traits that have traditionally been associated to men- which arguably makes her the patriarchal perpetrator of the film -as she exerts violence against other female characters, her mother and Thomas's wives, in the domestic sphere of the family house.

Whilst the siblings' romantic bond and dual condition seem unbreakable, these are eventually destroyed after Thomas falls in love with Edith. This is a turning point for him in the film, as he realises that the incestuous relationship with his sister is unnatural and that their murderous cycle needs to stop, but Lucille cannot accept her brother's betrayal. As Weeber points out, Thomas's «connexion with Lucille fades and neither sibling is able to survive» (2018: 124). Towards the end of the film, Lucille kills her brother because she cannot bear to lose that part of herself, although she is later killed by Edith, assisted by Thomas's nearly translucent ghost. Indeed, the ghosts' physical appearance is highly symbolical in the film. Thomas's wives are portrayed as spooky, fleshy skeletons covered in a thick blood-red tinge, whilst Thomas's ghost is an almost transparent, disembodied humanlike figure. The eerie appearance of the wives seems to point to their violent deaths, as well as to the blood-red clay present underneath the house where they were buried, which gives the estate its colloquial name: Crimson Peak. Thomas, however, seems to have been granted human-like features thanks to his love for Edith and his assistance in killing Lucille. This could be deemed his final act of redemption, as his ghost vanishes from the house shortly afterwards, along with those of his previous wives. 
They leave the haunted estate to rest in peace, once the traumatic cycle of violence has been stopped.

\section{THE RETURN OF THE DEAD IN CRIMSON PEAK}

The most prominent uncanny event in Crimson Peak is the return of the dead. Freud asserts that our fear of ghosts has its origin in in the common belief that the dead come back as enemies of the living and their purpose is to condemn the latter to their same dark fate (2001 [1919]: 242). Curiously enough, the ghosts that appear in Crimson Peak do not conform to this norm, as they are not antagonistic characters who plot against the female protagonist, but quite the opposite. In fact, Del Toro claims that he did not want to portray these spectres as evil, but rather as Edith's guides and protectors (2015b: 125). As mentioned above, the portrayal of supernatural creatures as guides and helpers is a common occurrence in Del Toro's films, most notably in The Devil's Backbone, where Santi's ghost helps and protects the kids in the orphanage. In Crimson Peak, the spectres are constructed as female allies -the tortured souls of wronged and abused women who try to protect Edith from the villains of the story. Indeed, all the ghosts that interact with the heroine in the film are female: Edith's mother and Thomas's mother and wives, who had been poisoned by Lucille, the patriarchal perpetrator. As discussed above, despite the fact that Lucille is a woman, she assumes the role of the patriarchal villain by adopting personality traits that have been traditionally associated to male perpetrators: violence, authority and control over other female characters in the domestic sphere.

The latter ghosts appear halfway through the film, once Edith and Thomas are living in the Sharpe estate. They try to warn Edith about the siblings' pernicious nature and to persuade her to flee from Allerdale Hall by haunting her dreams and the house at night. In both cases, they warn her to leave the house. Thomas' mother tells her, «leave here now» (Del Toro 2005: 01:05:41), and the rest give Edith clues that enable her to discover the siblings' incestuous relationship (Del Toro 2015a: 01:29:05). Before she was murdered, one of Thomas's wives recorded her traumatic experience as a warning for his future brides in a wax cylinder that Edith finds hidden in the basement of the mansion. She explains that the only thing that the siblings wanted was her money to modernise the family mines, and that Lucille had been poisoning her from the start (Del Toro 2015a: 01:21:56):

I wish I had the strength to leave, but I can't. All they want is my money to work on that infernal machine of his. That's all they care about. I will hide these cylinders away in the linen closet. Should anyone find them, let it be known that they did this. I must stop recording now. I can hear them coming. To whoever finds this, know that they are killing me. I'm dying. The poison is in the tea. Find my body, take it home. I don't want to die this far from home.

This incorporation of narrative voices and testimonies from the past is a common technique of neo-Victorian trauma narratives, where, as Heilmann and Llewellyn point out, both Victorian and contemporary identities, «narrators, 
voices, letters, diary entries, recollections, reflections, dreams, and documentary sources all blend together, mimicking the narrative devices, structures, and collage techniques of nineteenth-century and Victorian realist and Gothic literature» (2010: 34). Likewise, Kohlke and Gutleben suggest that a common strategy to trope trauma in neo-Victorian fiction, and to establish and empathic connection between the traumatised character and the audience, is the «encapsulation of the referential trauma in an object or -work within the novel itself, functioning as a sort of mise en abymen, through which the need to express the suffering can be attained (2010: 25). I argue that the wives' recording cylinders and documents that Edith finds in the basement are a clear example of this technique, since their suffering is conveyed through them. Thus, when Edith listens to these recordings, she bears witness to the wives' pain and becomes aware of the patriarchal violence that she -and all these women before her- have been subject to by Thomas and his sister. According to Maya Deren and Tracey Moffat, bearing witness requires several levels of empathy. First, one has to acknowledge that an atrocity has taken place (2005: 122) and that the victim's experience is real, even though we might not fully understand it (2005: 124). Then, one must take responsibility for this injustice (2005: 124) by showing a desire to change the world where similar injustices take place (2005: 122). I argue that Edith bears witness to the female ghosts' experience of domestic violence, as she takes responsibility and action against it by murdering Lucille, the patriarchal perpetrator. In doing so, the film is indirectly addressing its audience to empathise with these victims of gender violence, a traumatic experience that still prevails in contemporary societies.

Indeed, these female ghosts are the embodiment of women who have historically been -and still continue to be- lost to patriarchal violence. As Galiné claims, these female ghosts «uphold the Victorian conventions of staging spectralized women to expose the societal and patriarchal 'burying alive' which they are the victims of» (2020: 9). Moreover, they are examples of what Jessica Cox deems Victorian women that have been traumatised by the endless cycle of abuse inflicted upon them by the patriarchal system (2014: 137). I contend that these female spectres create a sorority of guardian spirits that try to protect Edith from meeting their same fate. Just as Edith's mother is a prophetic figure that guides and protects her daughter, Thomas's wives and mother try to spare her from the atrocious experiences they suffered at the hands of Lucille. I argue that this act of sorority conveys an empowering message for female viewers: women can survive and thrive in this patriarchal world despite their vulnerable circumstances, as long as they remain united and support each other. In fact, Cox asserts that trauma narratives seem to be characterised by a «search for identity and the challenge to established gender roles, as well as the effects of traumatic experience on an individual -[as they] continue to appeal to modern audiences» (2014: 137). Consequently, the ghosts that Edith encounters are actually feminist allies, whereas Lucille would encapsulate the patriarchal violence exerted on women across history. Thus, the female ghosts are «representing -and performing- the sympathy» to pain that is needed to create a "community of suffering». This way, the film is indirectly addressing the audience to «create an analogous community of feeing [...] outside of/beyond the world 
of the text", so that they can act as empathic witnesses towards the characters' traumas (Kohlke and Gutleben 2010: 28). This ethical involvement on the part of contemporary audiences might establish a connection between the Victorian and contemporary periods in that some nineteenth-century traumas still resonate well into the twenty-first century, particularly in the case of gender violence. Gender violence run rampant during the Victorian era and was commonly accepted by society (Wiener 2004), but it is a social concern still prevalent in present societies. In 2019, an estimated $7.5 \%$ of women (1.6 million) experienced domestic abuse in the UK (Office for National Statistics). Indeed, Deren and Moffatt claim that films portraying gendered traumas are fundamental for the audience to bear witness, as "[c]ommunities everywhere need to establish structures within which there can be "witnesses" for the testimony of women who are still subject to patriarchal violence» (2005: 135). Therefore, in this case neo-Victorian trauma narratives in general, and Crimson Peak in particular, would be reflecting one of neo-Victorianisms main characteristics: adopting a "dual approach», whereby it addresses both past and present anxieties (Hadley 2010: 6).

Edith, on the other hand, is the only female survivor, portrayed as an avenging angel that kills the villain and redresses the violence that Thomas's wives have gone through, restoring the social order. In fact, Roche asserts that the end of the film exploits the so-called final girl trope ${ }^{3}$, paying homage to slasher films and «enabling Edith to fulfil her destiny to survive» (2019: 87). The film closes with Edith's last voice-over, where she re-states her belief in the existence of ghosts and why some of them are condemned to remain in a particular place for all eternity (Del Toro 2015a: 01:50:04):

Ghosts are real. This much I know. There are things that tie them to a place, very much like they do us. Some remain tethered to a patch of land. A time and date. The spilling of blood. A terrible crime. But there are others. Others that hold onto an emotion. A drive. Loss. Revenge. Or love. Those, they never go away.

Lucille belongs to this latter category, since her inability to let go of her vicious past and her unnatural love for her brother condemn her to be the only remaining spectre haunting Allerdale Hall. Nonetheless, it is not clear whether Edith manages to overcome her traumas, since the film ends when she leaves the house. Murphy argues that she does not really find a sense of closure, since "the last vision we have of Edith is her face, turning back to the house, to the past. We never see her truly pass the gates into the outside world» (2016: 118-119). For Weeber, however, the film's circular structure draws attention to its nature as an extended flashback that lasts the entire movie, since it starts and finishes with the very same dialogue: "ghosts are real. This much I know». In doing so, Weeber claims that

3 The final girl trope is typical of slasher and horror films, wherein the only survivor is a female character. She is the last person to confront the murderer and usually survives to talk about the tragedy (Christensen 2011: 24). 
«Del Toro hints that the whole movie is a never-ending re-enactment of Edith's emancipation, of the violence she lived in Allerdale Hall» (2018: 119). However, I argue that the whole film should be considered as Edith's own trauma narrative through which she might achieve her cathartic release. This is proven by the fact that she acts as the narrator and focaliser of the film and the only female survivor. Moreover, the film beings and ends with the opening and closing of a book named «Crimson Peak by Edith M. Cushing» (Del Toro 2015a: 01:51:23). This shows that the film is constructed as a trauma narrative where Edith transforms her traumatic experience into storytelling, so that the audience can bear witness to her and the other female characters' traumas at the hands of the Sharpe siblings.

Finally, it is also worth noting that by representing different ways to trope trauma, Crimson Peak is encouraging its audience to empathise with the traumatised characters. As discussed above, representing trauma through its encapsulation in an object, constructing a trau matic metanarrative and establishing a community of feeling within the trauma narrative are three of the most common ways to represent trauma (Kohlke and Gutleben 2010). In Crimson Peak, Edith transforms her unresolved mourning into storytelling by writing ghost stories, and later on attempts to work through the traumatic experience of domestic violence by creating the trauma narrative that is the film itself. Thomas's wives verbalise their own gendered trauma by recording it in wax recording cylinders, which function as an encapsulation of the referential trauma through which they can fulfil the need to express their ordeal. Finally, the siblings attempt to work through their childhood trauma of domestic abuse by verbalising it and sharing it with Edith. Moreover, I argue that the female ghosts create a community of feeling inside the film to help Edith vanquish the patriarchal perpetrator, which might encourage the audience to empathize with their traumatic experiences. As Kohlke and Gutleben claim, neo-Victorianism transforms trauma experience into solidarity and sympathetic collaborations among survivors and witnesses, but also ensures a continuity between Victorian and present traumas (2010: 28). This is the case of Crimson Peak, as it depicts the timeless horrors of patriarchal violence - which still resonate well into the twenty-first century - and offers a sympathetic reading of the victims' and survivors' suffering.

\section{CONCLUSION}

Screen Victoriana displays a temporal duplicity between the Victorian and contemporary periods that allows us to explore historical traumas that still prevail at present. Consequently, the nineteenth century could be interpreted as an uncanny revenant from the past that permeates our present and forces us to address these timeless anxieties. In this article, I have argued that Crimson Peak is constructed as a neo-Victorian trauma narrative that exploits the trope of the uncanny-particularly the double, repetition compulsion and the return of the dead- to represent the trauma of gender violence and how it affects women.

Trauma survivors have an imperative need to verbalise their traumatic experience, so that a sympathetic listener can bear witness to and help them work 
through their pain. In Crimson Peak, Edith first fictionalises the unsuccessful mourning of her mother's death and the interactions with her spectre in the form of ghost stories. Through this metanarrative, Edith articulates and attempts to share her pain with her potential readers, who would act as empathic listeners. However, this potential empathic connection is curtailed in the end, as she cannot get her stories published and her only reader, Thomas, cannot act as an empathic addressee since he is actually one of the villains of the film. Moreover, I maintain that this trauma metanarrative is embedded in a larger trauma narrative, the film itself, whereby Edith verbalises, and attempts to work through, the suffering that she endures during her stay in Allerdale Hall. The idea that the film is constructed as Edith's trauma narrative is supported by the fact that she is the focaliser of the story, which starts and finishes with the opening and closing of a book, whose author is Edith herself. She is also the only survivor of the story and its narrator, as she introduces and finishes the story through the two voice-overs where she states her belief in the existence of ghosts. However, given that the film ends right after Edith leaves Allerdale Hall and all its horrors behind, and we do not know what happens to her afterwards, we cannot know for certain whether she actually overcomes her traumatic experience or not.

Moreover, Thomas's murdered wives and mother also construct their own trauma narratives by recording their experiences in wax cylinders, which function as a mise en abyme of their trauma, in order to warn Thomas's future wives of the siblings' intentions. This narrative mechanism is a frequent trope in trauma narratives that helps establish an empathic connection between the traumatised character and the audience. These uncanny revenants represent the ever-present gendered trauma of domestic violence across history, and join forces in a community of feeling in order to protect Edith from the siblings' patriarchal violence. Thus, Crimson Peak is an example of historical narratives of trauma that act as a fictional space of reflection for contemporary audiences. This way, they can develop empathy for the traumatised characters and address the multitemporal issue of gender violence. 


\section{BIBLIOGRAPHY}

Austen, Jane (2008 [1817]): Northanger Abbey, London: Random House.

Arias, Rosario, and Patricia Pulham (2009): «Introduction», in Haunting and Spectrality in Rosario Arias and Patricia Pulham (eds.), Neo-Victorian Fiction: Possessing the Past, eds., Hampshire: Palgrave Macmillan, XI-Xxv.

Busch, Brigitte and Tim McNamara (2020): «Language and Trauma: An Introduction», Applied Linguistics 41 (3): 323-333. URL: https://academic.oup.com/applij/article/41/3/323/5821459.

Claassens, L. Juliana (2020): «Reading Trauma Narratives: Insidious Trauma in the Story of Rachel, Leah, Bilhah and Zilpah (Genesis 29-30) and Margaret Atwood's The Handmaid's Tale», OTE Journal33 (1): 10-33. URL: https://journals.co.za/doi/pdf/10.17159/2312-3621/2020/ v33n1a3.

Cox, Jessica (2014): «Narratives of Sexual Trauma in Contemporary Adaptations of The Woman in White», in Nadine Boehm-Schnitker and Susanne Gruss (eds.), Neo-Victorian Literature and Culture: Immersions and Revisitations, New York, London: Routledge, 1137-1149.

Christensen, Kyle (2011): "The Final Girl versus Wes Craven's "A Nightmare on Elm Street": Proposing a Stronger Model of Feminism in Slasher Horror Cinema», Studies in Popular Culture 1: 23-47.

Del Toro, Guillermo (dir.) (2001): The Devil's Backbone, Spain: Canal + España.

Del Toro, Guillermo (dir.) (2015a): Crimson Peak, USA: Legendary Pictures and Double Dare You Productions.

Del Toro, Guillermo (dir.) (2015b): «Ghost Hunter». Interview by Mar Diestro-Dópido[interview], Sight and Sound.URL: http://sightandsounddigital.bfi.org.uk/custompages/SightAndSound/ subscribe.aspx.

Deren, Maya and Tracey Moffatt (2005): «The Ethics of Witnessing», in E. Ann Kaplan (ed.), The Politics of Terror and Loss in Media and Literature, New Jersey: Rutgers University Press, 122-135.

Freud, Sigmund (2001 [1919]): «The Uncanny», in James Stachey (ed.), Anna Freud (trans.), The standard edition of the complete psychological works of Sigmund Freud, volume XVII (19171919): An infantile neurosis and other works, London: Vintage, 217-252.

Freud, Sigmund (2001 [1917]): «Mourning and Melancholia», in James Stachey (ed.), Anna Freud (trans.), The standard edition of the complete psychological works of Sigmund Freud, volume XVII (1917-1919): An infantile neurosis and other works, London: Vintage, 243-258.

Galiné, Marine (2020): “'Capture a Feeling of the Old”: Guillermo Del Toro’s Crimson Peak (2015) and the Victorian Gothic», Polysèmes. Revue d'études intertextuelles et intermédiales 23: 1-16. URL: https://journals.openedition.org/polysemes/pdf/6872.

Ganteau, Jean Michel and Susana Onega (2011): «Introduction», in Jean Michel Ganteau and Susana Onega (eds.), Ethics and Trauma in Contemporary British Fiction, Leiden: Rodopi B.V, 7-19.

Gruss, Susanne (2014): «Spectres of the Past: Reading the Phantom of Family Trauma in NeoVictorian Fiction», in Nadine Boehm-Schnitker and Susanne Gruss (eds.), Neo-Victorian Literature and Culture: Immersions and Revisitations, New York, London: Routledge, 123136. 
Hadley, Louise (2010): Neo-Victorian Fiction and Historical Narrative: The Victorians and Us, Hampshire: Palgrave Macmillan.

Heilmann, Anne and Mark Llewellyn (2010): Neo-Victorianism: The Victorians in the TwentyFirst Century, 1999-2009, London: Palgrave Macmillan.

Henke, Suzette A. (1998): Shattered Subjects: Trauma and Testimony in Women's Life Writing, London: St. Martin's Press.

Kohlke, Marie-Luise and Christian Gutleben (2010): «Introduction: Bearing After-Witness to the Nineteenth Century», in Marie-Luise Kohlke and Christian Gutleben (eds.), Neo-Victorian Tropes of Trauma: the Politics of Bearing After-Witness to Nineteenth-Century Suffering, Amsterdam: Rodopi, 1-34.

Kohlke, Marie-Luise and Christian Gutleben (eds.) (2012): Neo-Victorian Gothic. Horror, Violence and Degeneration in the Re-Imagined Nineteenth Century, Amsterdam: Rodopi.

LaCapra, Dominick (2001): Writing History, Writing Trauma, Baltimore: The John Hopkins UP.

LAub, Dori (1992a): «An Event Without a Witness: Truth, Testimony and Survival», in Shoshana Felman and Dori Laub (eds.), Testimony: Crises of Witnessing in Literature, Psychoanalysis, and History, New York, London: Routledge, 75-92.

Laub, Dori (1992b): «Bearing Witness or the Vicissitudes of Listening», in Testimony: Crises of Witnessing, in Shoshana Felman and Dori Laub (eds.), Literature, Psychoanalysis, and History, New York, London: Routledge, 57-74.

Loutrit, Chris and Erin Loutriт (2018): «Introduction: Screening the Victorians in the TwentyFirst Century», Neo-Victorian Studies 11 (1): 1-14. URL: http://www.neovictorianstudies. com/past_issues/11-1\%202018/NVS\%2011-1-0\%20C-Louttit\%20E-Louttit.pdf.

Lukancic, Khara (2018): «Modifying the Gothic: Gender in Crimson Peak». Paper given at the Popular Culture Association National Conference, Indianapolis, March 2018.

Maier, Sarah E. and Brenda Ayres (2020): «Introduction: Neo-Gothicism: Persistent Haunting of the Past and Horrors Anew», in Sarah E. Maier and Brenda Ayres (eds.), Neo-Gothic Narratives: Illusory Allusions from the Past, London and New York: Anthem Press, 1-12.

Mitchell, Kate (2010): History and Cultural Memory in Neo-Victorian Fiction: Victorian Afterimages, Hampshire: Palgrave Macmillan.

Murphy, Beatrice. M (2016): "Crimson Peak», The Irish Journal of Gothic and Horror Studies 15: 159-63. URL: https://irishgothichorror.files.wordpress.com/2016/02/issue-15-full-final.pdf.

Musap, Emilia (2017): «Monstrous Domesticity-Home as a Site of Oppression in Crimson Peak», SIC: A Journal of Literature, Culture and Literary Translation 1 (8): 1-14. doi: 10.15291/ sic/1.8.lc.3. URL: https://hrcak.srce.hr/191184.

Mustafa, Jamil (2018): «Representations of Masculinity in Neo-Victorian Film and Television», Neo-Victorian Studies 11 (1): 38-64.

Office for national statistics (2020): Domestic Abuse Victim Characteristics, England and Wales: Year Ending March 2019. URL: https://www.ons.gov.uk/peoplepopulationandcommunity/ crimeandjustice/articles/domesticabusevictimcharacteristicsenglandandwales/ yearendingmarch2019.

Pedro, Dina (2020): «Challenging the Victorian Nuclear Family Myth: The Incest Trope in Guillermo del Toro's Crimson Peak", Atlantis: Journal of the Spanish Association of Anglo-American Studies 42(1): 76-93. URL: https://www.atlantisjournal.org/index.php/atlantis/article/view/616. 
Petrie, Charles (2000): «Victorian Women Expected to Be Idle and Ignorant», in Clarice Swisher (ed.), Victorian England, San Diego: Greenhaven Press, Inc, 178-187.

Primorac, Antonija (2018): Neo-Victorianism on Screen: Postfeminism and Contemporary Adaptations of Victorian Women, Hampshire: Palgrave Macmillan.

Roche, Hayley Arizona (2019): «Celebrating Imperfection through Perfect Images: Guillermo del Toro's Work», Studies in Arts and Humanities, 1 (2): 80-91.

Scotт, A. O. (2015): “Crimson Peak”, a Guillermo del Toro Gothic Romance in High Bloody Style», New York Times. URL: https://www.nytimes.com/2015/10/16/movies/crimson-peak-aguillermo-del-toro-gothicromance-in-high-bloody-style.html.

Vickroy, Laurie (2002): Trauma and Survival in contemporary Fiction, Virginia: University of Virginia Press.

Weeber, Rose-Anaïs (2018): «Crimson Peak: Guillermo del Toro's Visual Tribute to Gothic Literature», Caietele Echinox 35: 115-126.

Wiener, Martin J. (2004): Men of Blood: Violence, Manliness, and Criminal Justice in Victorian England. Cambridge: Cambridge UP. 